\author{
Arif Huseynov, \\ Dr.Sc., Azerbaijan State Oil and Industry University, Azerbaijan \\ ORCID ID, 0000-0003-0504-745X \\ Emil Huseynov, \\ Oil and Gaz Research and Design Institute, Azerbaijan \\ (iD) ORCID ID, 0000-0001-9663-5198 \\ Yaryna Samusevych, \\ Ph.D., Sumy State University, Ukraine \\ (iD) ORCID ID, 0000-0001-7048-8388 \\ Correspondence author: arif.huseynov@asoiu.edu.az
}

\title{
INNOVATIVE DEVELOPMENT OF OIL \& GAS INDUSTRY: ROLE OF ENVIRONMENTAL TAXATION
}

Abstract. The article is devoted to studying the relationship between environmental taxes and the innovative development of the oil and gas industry. The bibliometric analysis of the directions of scientific research of the chain «innovative management - oil and gas industry - environmental taxes» testified to the central place of the issue of sustainable development in ensuring innovative transformations of the industry. It is determined that at the present stage, the application of environmental taxes aims not only to reduce environmental pollution but also to ensure structural transformations of the economy on the way to ensuring its sustainable development. It has been proven that innovations in the oil and gas ind ustry are connected with implementing more efficient technologies and the search for prospects for its transformation under the green economy goals. It is determined that the application of environmental taxes to stimulate sustainable development progress requires the complexity of their application with other instruments of state support for environmental innovation. An empirical analysis of the relationship between environmental taxation and oil and gas production and consumption using statistics for OECD countries for 20102019. Correlation analysis results identified the inverse relationship between the dynamics of indicators of environmental tax intensity and the parameters of the oil and gas industry. Regression with Newey-West standard errors dependences of changes in oil and gas production and consumption under the influence of changes in environmental tax revenues confirmed the existence of an inverse relationship. It is determined that with the growth of tax revenues from environmental taxes, there are significant reductions in both production and consumption of oil and gas. Accordingly, it is confirmed that environmental taxes are one of the reasons for the innovative transformations of the oil and gas industry, associated with reducing its traditional operation and the transition to more advanced technologies for energy production. The obtained results create a basis for adjusting the state strategies for regulating the functioning of the oil and gas industry and ensuring its innovative development.

Keywords: environmental taxation, oil and gas industry, innovations, sustainable development, energy efficiency, sustainable growth, industrial innovation.

Introduction. The need to achieve the Sustainable Development Goals is linked to the transformation of all sectors of the national economy without exception. At the same time, the need for comprehensive restructuring is associated with some institutional challenges, including the government's willingness to implement and support sustainable development programs, agree on strategic guidelines for real sector transformation and find ways to balance economic, environmental, and social efficiency (Bhandari, 2019). The effectiveness of the tools of transition to a sustainable economy must depend not only on their design but also on the initial conditions of the national economy, the structure of its industry, and resource orientation (Biewendt, 2020). The asymmetry of regional and national development creates additional challenges related to the potential for industrial transformation, the duration of its restructuring, and the economic losses caused by the implementation of environmentally friendly technologies. It is proved that

Cite as: Huseynov, A., Huseynov, E., \& Samusevych, Y. (2021). Innovative Development of Oil \& Gas Industry: Role of Environmental Taxation. Marketing and Management of Innovations, 4, 79-91. http://doi.org/10.21272/mmi.2021.4-07 

Taxation

the specifics of applying tax instruments to limit the environmental impact of the national industry largely depend on the country's resource potential. Thus, particularly for countries rich in natural resources, using restrictive tools to use resources to achieve environmental effects can lead to significant economic shocks, which offset the overall results achieved (Eddassi, 2020). Despite the global nature of sustainable development, a radical restructuring of resource-oriented industries remains impossible, given both the need for the functioning of national economies and transnational trade (He, 2019). At the present stage, special attention is paid to the development of the energy sector, which, along with the growing role of renewable energy, remains largely dependent on fossil natural resources. Thus, even though the development of renewable energy is a progressive way to ensure national competitiveness (Ibragimov et al., 2019), at the present stage, it is still impossible to abandon traditional sources of its production. It is especially true for countries rich in fossil fuels, for which, in particular, the oil and gas industry is the basis of the national economy. At the same time, ensuring that the oil and gas industry's functioning meets the current priorities of global development also requires the introduction of appropriate transformations. In particular, the prospects for introducing innovative technologies to increase its efficiency, the potential for leveling security challenges, and the control of cross-border connections constantly remain relevant. It requires considering the current development priorities set by the world community, the development of research and development, and finding ways to transform. In this context, the relationship between regulatory incentives for a sustainable economy and the potential for innovative development of the oil and gas industry should be explored.

Literature Review. Issues of sustainable development and climate change at the present stage become key issues to ensure the environmental and social components of economic development and determine the economic efficiency of selected industrial development strategies. Thus, in particular, the carbon emissions trade has turned the issue of environmental pollution not only into an environmental but also into an economic problem for industrial enterprises. Dynamic changes in price indices in the carbon market indicate that the lack of environmental guidelines in the development of enterprise strategy creates additional risks of unforeseen economic shocks to its operation and can lead to significant economic losses (El Amri et al., 2021). The issues of the ecological orientation of the national economy determine its competitiveness and its recognition in the global environment (Bilan et al., 2019).

The variability of the global environment proves that the innovative way of economic development remains the only way to maintain its competitiveness. The issues of constant change, adaptability, innovative technological development were considered a key task of strategic management of the company in the mid-1990s (Teece et al., 1997) and do not lose their relevance to this day. Thus, in particular, the global Covid-19 pandemic demonstrated the importance of sustainable development, the need to apply transformation strategies to maintain and restore the pace of economic activity (Mishenina et al., 2021; Antonyuk et al., 2021). It has been proven that the chosen innovative path of development to build a green economy provides greater resilience of the business sector to unexpected global challenges (Us et al., 2020). At the same time, the problem of finding a balance between optimizing a company's overall costs and minimizing its impact on the environment is constantly attracting the attention of both researchers and corporate managers (Christmann, 2020). It has been proved that environmental innovations primarily depend on the company's internal management's effectiveness, particularly in terms of human resource management (Kasztelnik and Gaines, 2019). Thus, in the long run, the image of environmental responsibility can strengthen the company's competitiveness and form its added-value (Bonamigo and Mendes, 2019; Taliento and Netti, 2020). At the same time, it has been proven that complex, innovative transformations on the way to building a circular economy are inevitable and increasingly polished in the corporate sector (Berardi and de Brito, 2021).

Even though the issue of climate change has led to large-scale transformations of the energy sector (Gil et al., 2021), most environmental innovations remain economically inefficient for enterprises in the short term. In particular, the energy sector transformations are economically costly, long, and complex in 

Taxation

their implementation, which makes it impossible to implement them without proper state support. Thus, it has been proven that the level of energy efficiency of a country largely depends on public policy (Lyulyov et al., 2021; Pavlyk, 2020). At the same time, it is determined that the overall efficiency of natural resource use largely depends on the overall quality of the institutional environment of the national economy, which is enhanced by the impact of the achieved level of human and economic development (Khan and Kishwar, 2020). The main direction of implementing innovations in the oil and gas industry is to increase the efficiency of energy production (Adetutu, 2014). It is determined that the current challenges of the global environment determine the need to consider the challenges of sustainable development, even in the activities of resource-oriented companies in the oil and gas industry (Bansal, 2005). Results of surveys conducted by researchers among company management show that the implementation of innovations in the oil and gas industry is under pressure from the external regulatory environment and under the influence of companies' desire to gain future competitive advantage (Ford et al., 2014). At the same time, environmental taxation remains one of the most effective tools for transforming energy production (Acemoglu et al., 2012; Freire-González and Puig-Ventosa, 2019). It is determined that their role continues to be studied both in the scientific literature and through empirical research (Kemp and Pontoglio, 2011). In particular, the priority of environmental taxation over other instruments of state influence on technological innovation has not been proven (Fischer et al., 2003), which allows us to hypothesize the effectiveness of their various combinations. That is why the potential of innovative development of the oil and gas industry should be analyzed considering the state instruments of influence on its functioning.

Methodology and research methods. The study consists of two parts. The first part is devoted to generalizing theoretical relationships that arise in the chain «innovation management - oil and gas industry - environmental taxes». The bibliometric analysis of scientific articles indexed by the Scopus scientometric database was chosen as the research tool. The study was conducted in several stages:

1. Formation of the samples of articles indexed by the scientometric database Scopus, which simultaneously include two studied concepts: 1) «innovation» and «management», 2) «innovation» and «oil \& gas industry», 3) «oil \& gas industry» and «environmental tax», 4) «environmental tax» and «innovation».

2. Selection of the most cited articles, regardless of the period of their publication.

3. Analysis of the coincidence of keywords found in the titles, annotations, and lists of keywords of selected articles, generalization of the central areas of research of selected concepts.

4. Analysis of the chronology of the frequency of keywords in articles on the subject, determining the evolutionary patterns of research.

Implementation of bibliometric analysis was performed using the toolkit VOSViewer 1.6.1.

The second part of the study is devoted to the empirical analysis of the relationship between environmental taxation and the oil and gas industry development using correlation and regression analysis. A sample of the following variables was formed for calculations:

- Environmental taxes revenues, \% of GDP;

- Oil production; thousands of barrels per day;

- Natural gas production, billion cubic metres per year;

- Oil consumption, thousands of barrels per day;

- Natural gas consumption, billion cubic meters per year.

The statistical database is based on aggregate indicators for OECD countries. The study period covers 2010-2019. The study is built in terms of the following stages:

1. Multiple correlation analysis by calculating Pearson's correlation coefficients.

2. Testing of data for the selection of the relevant form of regression dependence.

3. Construction of regression models with Newey-West standard errors.

4. Interpretation of regression analysis results. 

Taxation

Results. Management of innovative development of the national economy is characterized by complexity and a significant number of areas of application, which are accompanied by constant quantitative and qualitative changes in the tools to stimulate innovation. A bibliometric analysis of 120,657 articles, indexed by the Scopus scientometric database, which contains both keywords such as «innovation» and «management», showed that the existing areas of research could be combined into three clusters (Fig. 1).

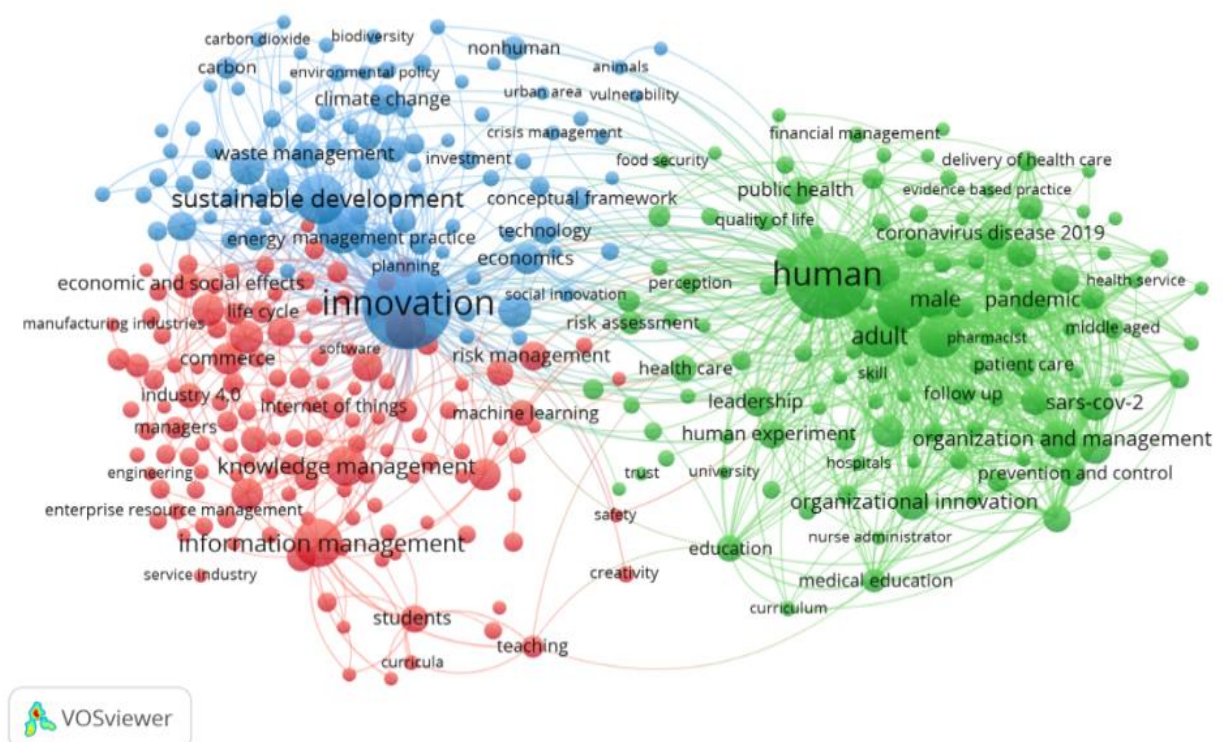

Figure 1. Results of bibliometric analysis of co-occurrence keywords on the request both «innovation» and «management» based on Scopus publications

Sources: developed by the authors.

The first largest (red) cluster combines 132 keywords, among which the most significant are information management, knowledge management, industry 4.0, internet of things. It shows that the current priority of innovative development is the provision of technological innovations that ensure the development of different economic spheres. In second place in terms of scale is the green cluster, which includes 111 keywords, including human, pandemic, covid-19, prevention, and control, which is associated with modern pandemic challenges and the need to find innovative methods of post-pandemic recovery. The third (blue) cluster contains 92 keywords, with such central concepts as sustainable development, environmental management, sustainability, climate change. That ensures the transition to sustainability and environmental orientation, which is associated with promoting energy efficiency, circular and zerowaste economy.

Analysis of the chronology of the use of keywords in the most cited publications on innovation management (Fig. 2) showed that in the early 2000s, innovative enterprise management was associated primarily with gaining competitive advantage, updating the product line of enterprises, developing relations with internal and external stakeholders of enterprises, etc. 


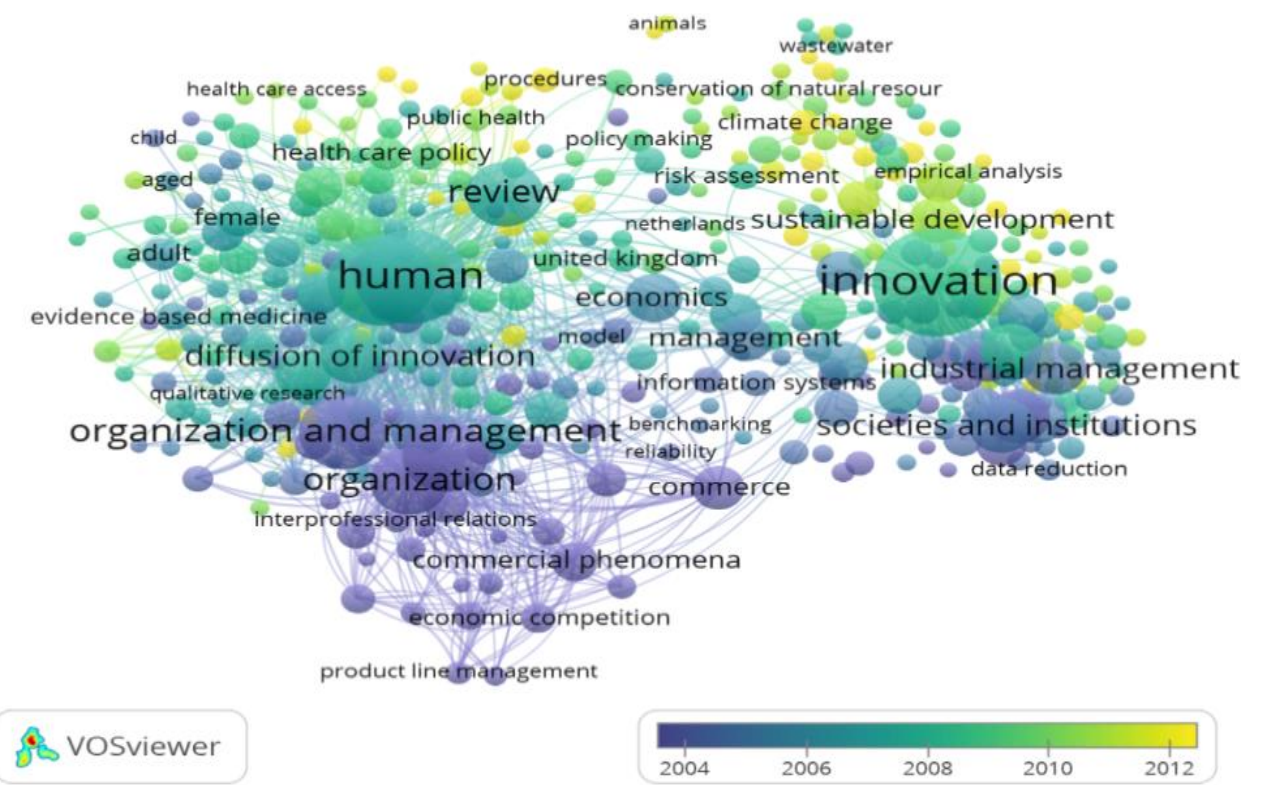

Figure 2. Results of bibliometric analysis of keywords chronology on the request both «innovation» and «management» based on Scopus publications

Sources: developed by the authors.

The post-crisis period of $2008-2010$ is already accompanied by the transition to information management and knowledge economy. The issues of personnel management of enterprises are in the first place. At the same time, the most modern research in the field of innovation management concerns the fight against climate change, the search for innovative management solutions in environmental protection, the fight against the destructive impact of industry on the environment. It indicates the need to transform management approaches in all areas of the national economy, highlighting the Sustainable Development Goals as a priority for maintaining long-term competitiveness and achieving leadership positions in the public consciousness.

At the same time, it should be noted that the scaling of innovations in the context of sustainable development of the industry inevitably leads to its transformation by displacing outdated energy inefficient and environmentally hazardous technologies, replacing individual products with environmentally neutral counterparts, and more. The extractive industry is of considerable scientific and practical interest in this context. On the one hand, its direct impact on environmental degradation by reducing available natural resources, disrupting the natural landscape, environmental pollution by by-products of mining. On the other hand, the restructuring process of the world economy, given that reducing the consumption of natural resources is too long, requires significant investment and radical restructuring of technology. In particular, the energy sector is developing rapidly today. New ways of using renewable energy, obtaining energy from waste, increasing energy efficiency, etc., are emerging and spreading, which will undoubtedly lead to a reduction in energy production. At the same time, the uneven economic and technological development of individual countries is noticeable in the world economy, which affects the radically different ratios of renewable energy used and energy from fossil sources. It indicates that future changes in the extractive industry would be inevitable but significantly delayed. Therefore, it is necessary to analyze modern research on innovations in the development of the extractive industry, namely in the field of oil 

Taxation

and gas. The results of the bibliometric analysis presented in Fig. 3 testify to the existence of the three largest areas in which research and implementation of innovations in this area.

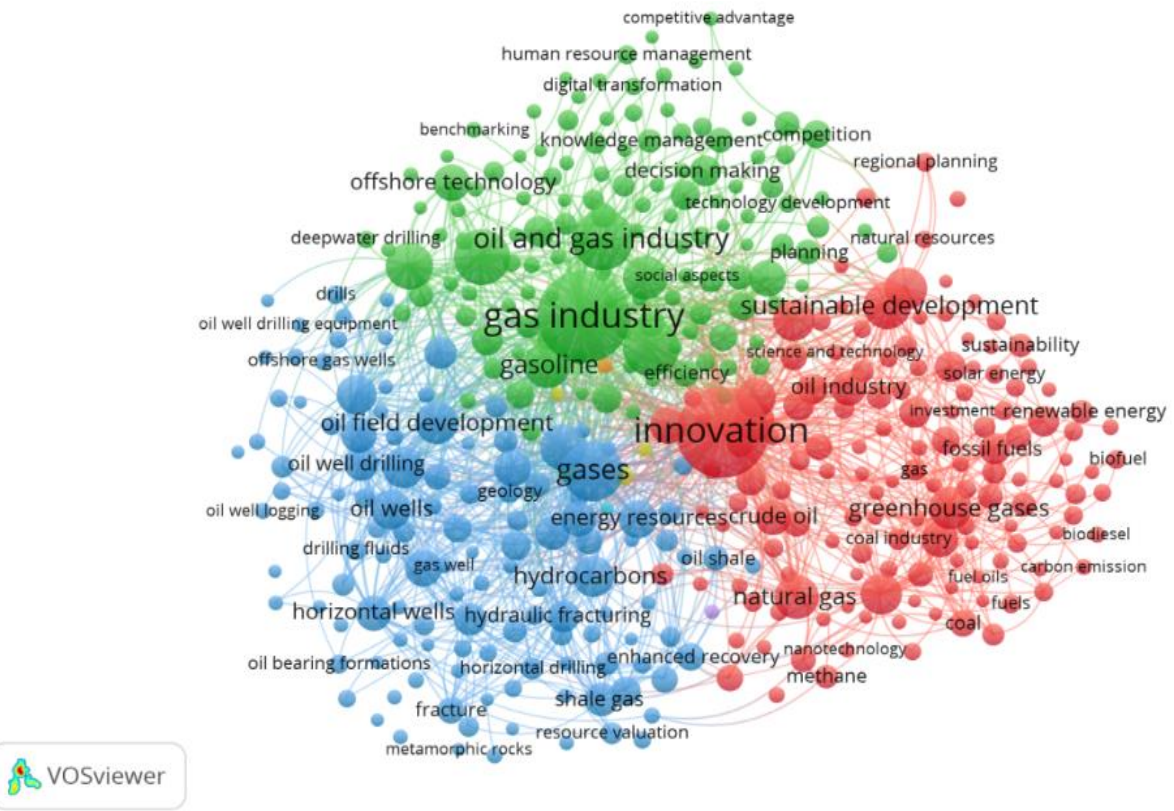

Figure 3. Results of bibliometric analysis of co-occurrence keywords on the request both «oil \& gas» and «innovation» based on Scopus publications

Sources: developed by the authors.

Thus, the first largest cluster (red) combines 148 keywords. The central place is occupied by greenhouse gases, energy policy, solar energy, environmental technology, renewable energy, climate change reflecting the scale of the problem of transforming the structure of energy produced and used to achieve environmental orientation of the energy sector. The direction of overcoming security challenges and ensuring the technological development of the energy sector (green cluster) is in second place. It contains 127 keywords, including knowledge management, technology innovation, safety engineering, accident prevention, decision making, and digital transformation. The third large-scale research area of innovation in the oil and gas industry (blue cluster) includes 119 keywords. A special place is occupied by oil wells, infill drilling, hydraulic fracturing, shale gas, horizontal wells, fracture, enhanced recovery, etc. This cluster combines research in the field of oil and gas technology, the search for new advanced ways of oil and gas production with maximizing productivity and minimizing losses.

Analysis of the chronology of research development (Fig. 4) showed that earlier publications are devoted to developing structural components of the oil and gas industry, process planning of production, and storage of oil and gas. At the same time, the latest scientific research is already linked to climate change, sustainable development, digital transformation, and the impact of renewable energy. 


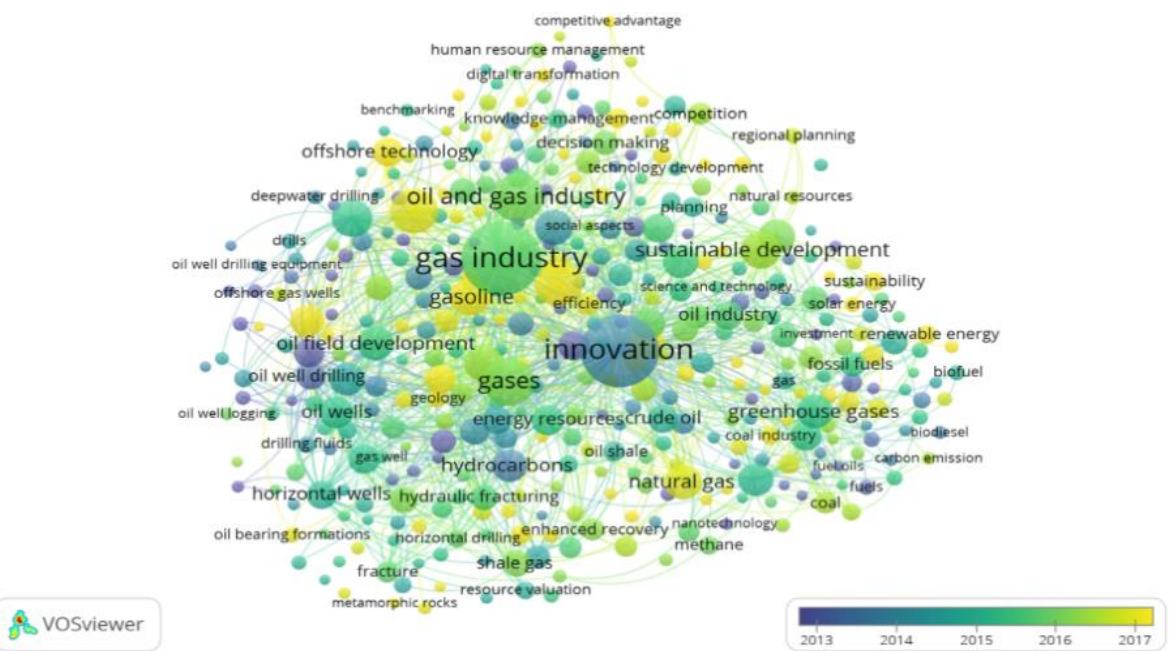

Figure 4. Results of bibliometric analysis of keywords chronology on the request both «oil \& gas» and «innovation» based on Scopus publications

Sources: developed by the authors.

The priority of ecologically oriented transformations of the national economy leads to corresponding changes in the system of its state regulation. Thus, the need to generate additional capital to preserve and restore the environment and limit the destructive impact cause the strengthening of deterrent instruments of state influence on extensive economic technologies. For industries related to the direct use of natural resources, this role is primarily played by resource payments. The bibliometric analysis of research on the application of environmental taxes in view of the development of the oil and gas industry (Fig. 5) showed the five largest areas mediated by the relevant clusters.

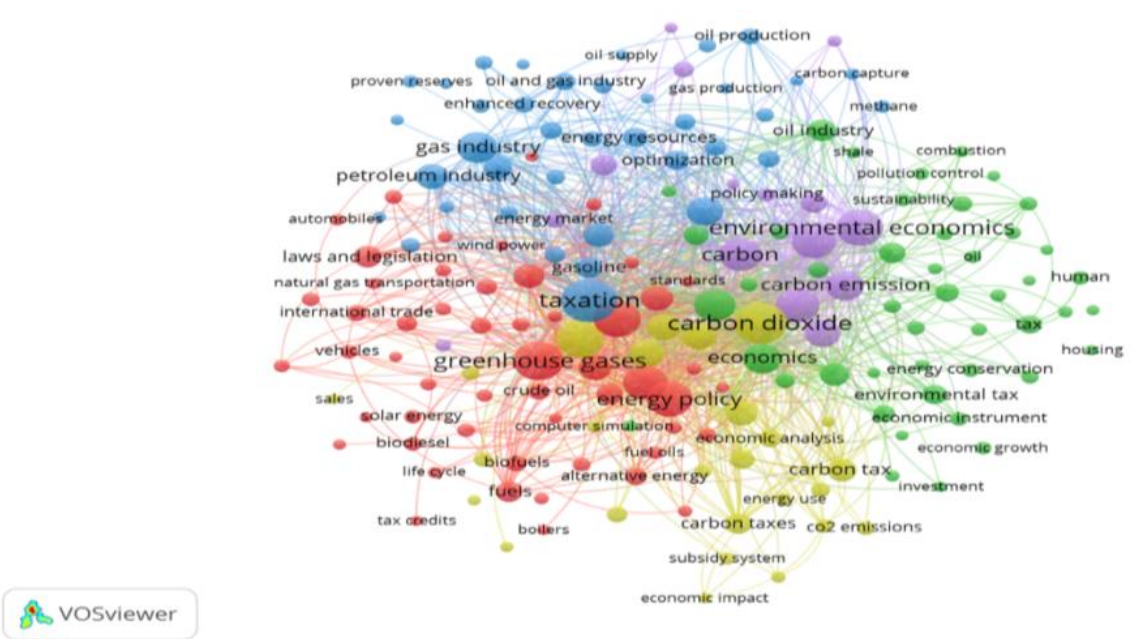

Figure 5. Results of bibliometric analysis of co-occurrence keywords on the request both "environmental tax» and "oil \& gas» based on Scopus publications

Sources: developed by the authors. 

Taxation

The largest (red) cluster includes 53 keywords. It reflects the direction of environmental impacts associated with the use of energy resources, as well as the potential for general structural transformations of the energy sector, mediated by keywords such as environmental impact, greenhouse gases, fuels, industrial emission, fuel economy, natural gas transportation, petroleum transportation, commerce, solar energy, biomass, vehicles. The green cluster ( 46 keywords) is in second place. It focuses on environmental protection, economic development, electricity, sustainability, air pollution, energy conservation, reflecting the long-term strategic links that arise when applying environmental taxes in the oil and gas industry, the need to balance economic and environmental effects in the process of its operation. The third (blue) cluster contains 38 keywords, costs, investments, industrial economics, profitability, oil and gas production, which summarizes the complex economic effects of the oil and gas industry. The yellow cluster includes 26 keywords (energy policy, climate change, energy efficiency, budget control, laws and legislation, international trade, renewable resource), which characterizes the general place of the oil and gas industry in ensuring global energy potential. The last (purple) cluster consists of 15 keywords such as pollution tax, environmental economy, emission control, and carbon emission, which comprehensively reflects the ultimate goal of environmental taxes in the oil and gas industry to minimize destructive environmental impact. Thus, the application of environmental taxes in the oil and gas industry to minimize its environmental impact has several generalizing manifestations: the search for the optimal balance between environmental and economic effects, maximizing the efficiency of technological processes and production losses, transformation of the overall energy production structure. It proves the inevitability of systemic structural transformations of the energy sector and the need for preventive management by introducing innovative energy-efficient technologies.

Analysis of the evolution of scientific research (Fig. 6) showed that there has also been a change in approaches to determining the specifics of the impact of environmental taxes on the development of the oil and gas industry in recent decades.

\& vosviewer

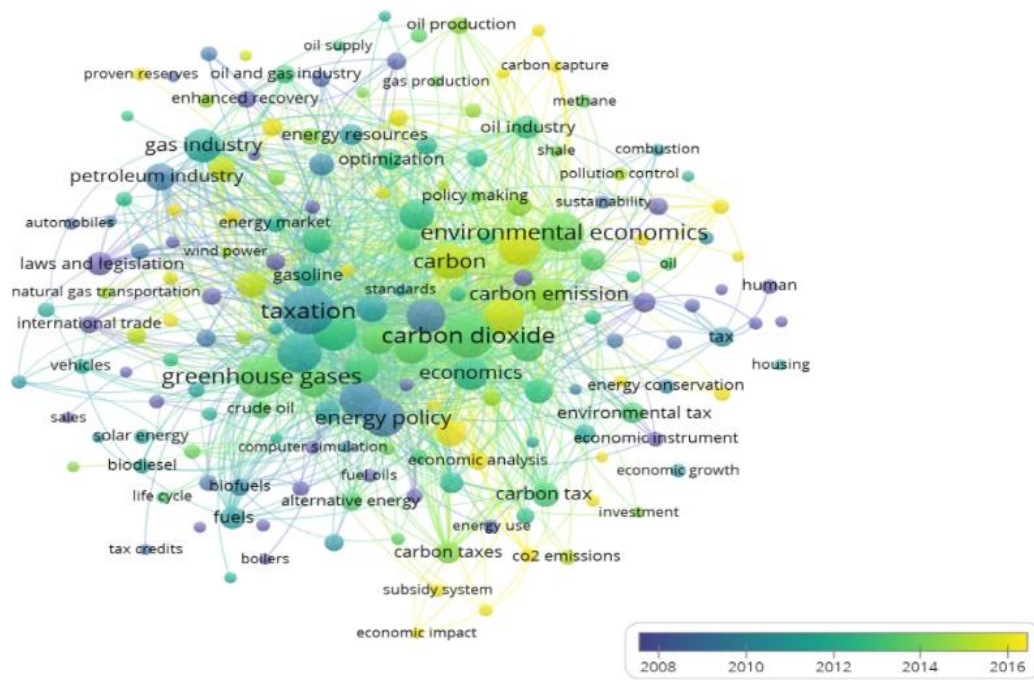

Figure 6. Results of bibliometric analysis of keywords chronology on the request both "environmental tax» and «oil \& gas» based on Scopus publications

Sources: developed by the authors. 
Thus, earlier research is related to the study of the level of environmental pollution, the specifics of the structure of production, the general development of the industry. At the same time, recent studies are more comprehensive, devoted to environmental economics, the overall economic efficiency of the oil and gas industry, the search for prospects for its transformation.

At the same time, the most open question remains whether environmental taxes lead to real innovation. Investigating these relationships, scientists analyze six key areas (Fig. 7).

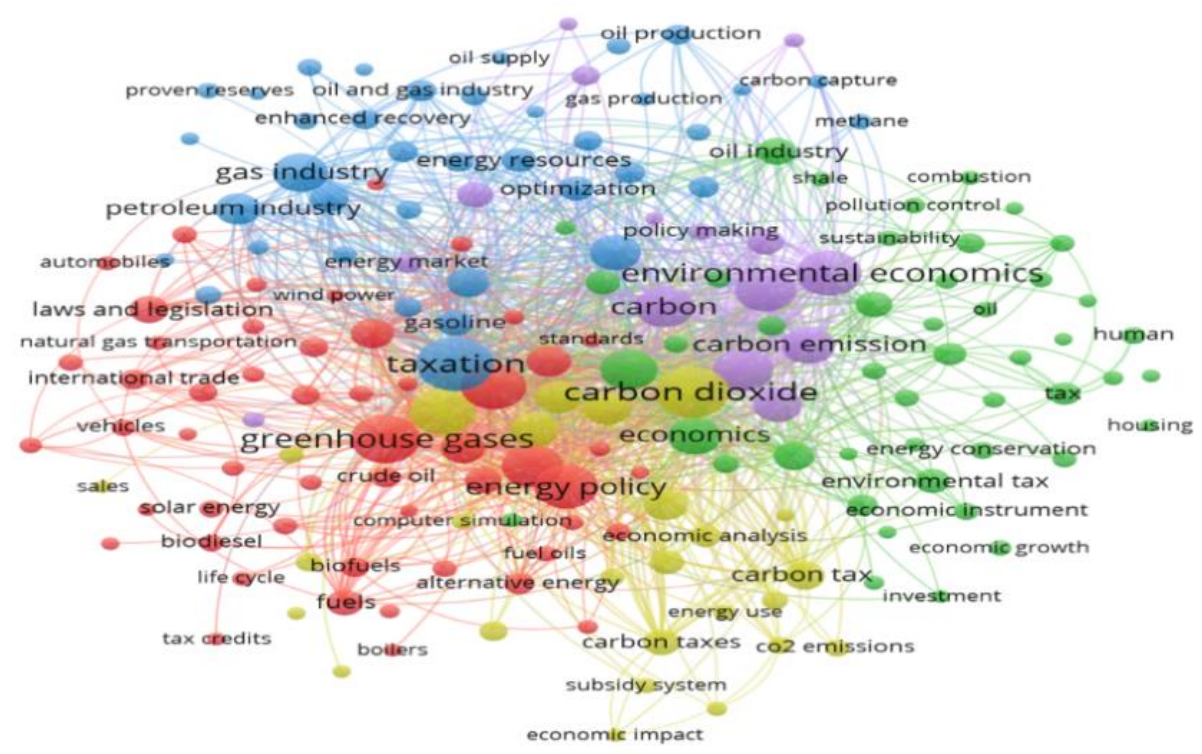

Figure 7. Results of bibliometric analysis of co-occurrence keywords on the request both «environmental tax» and «innovation» based on Scopus publications

Sources: developed by the authors.

The first direction (red cluster) contains 52 keywords. It reflects the economic instruments used to provide a stimulating effect on the transformation of the national economy. It mediates the scope of innovation due to the impact of environmental taxes (in particular, pollution tax, carbon pricing, policy strategy, investment, clean technologies, consumer behavior, technological change). The green cluster (47 keywords) is related to the economic effects of environmental taxes and the search for comprehensive solutions to ensure sustainable economic development under the influence of innovation, which would maximize the overall economic effect of environmental taxes (as evidenced by keywords such as climate policy, climate change, budget control, general equilibrium, technological development, power generation, abatement cost, mitigation). The blue cluster combines the keywords in the field of ecological transformations of the national economy, which are the targets for applying environmental taxes (a total of 41 keywords, including renewable energy, green economy, sustainable development, recycling). The fourth (yellow) cluster contains 31 keywords (pollution, social responsibility, environmental protection, etc.), which reflect the traditional role of environmental taxes in minimizing anthropogenic environmental impact. The purple cluster includes 31 keywords (low-carbon technologies, economic and social effects, global warming, low-carbon economy, energy conservation, emission control, laws, and legislation). They reflect the structural and institutional support for innovation due to environmental taxes and the implementation of economic ties that arise in innovative environmentally-oriented development. It includes public policy, game theory, planning, industry, decision making, and sales, reflecting the traditional 

Taxation

approaches to innovation management both at the level of individual enterprises and the scale of the national economy. The last direction (light blue cluster) concentrates on green innovation, which might be provided through environmental taxes. The uniformity of the scale of the five clusters formed shows that the impact of environmental taxes on the economy's innovative development is complex and mediated by complex transmission effects. Thus, ensuring the real transformation of industry in the transition to a sustainable economy is important not only the design of regulatory instruments but also balancing environmental and economic effects, infrastructural and institutional support for industrial environmental innovations, gradual and comprehensive development and implementation.

We also note the noticeable change in priorities in the chronological development of research in this area over the past decade (Fig. 8).

\& vosviewer

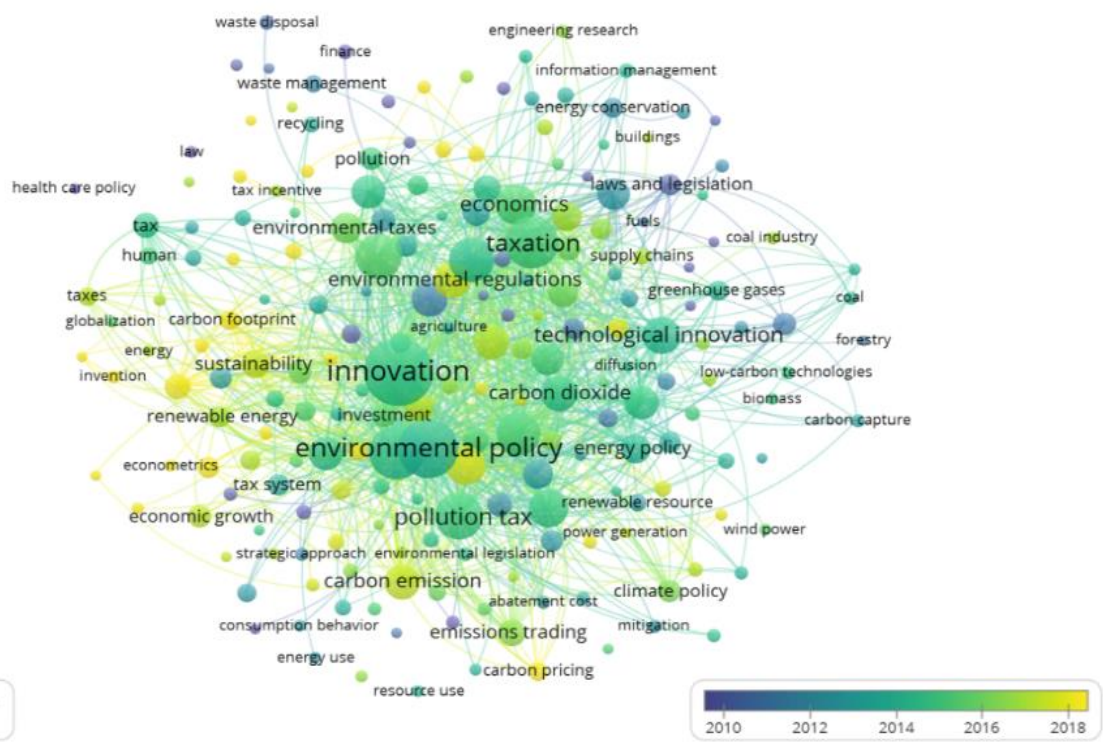

Figure 8. Results of bibliometric analysis of keywords chronology on the request both "environmental tax» and «innovation» based on Scopus publications

Sources: developed by the authors.

Thus, in 2010 the topics of environmental tax legislation, political strategies, environmental planning were actively studied, i.e., the overall design of environmental tax instruments in the development of innovative development was developed. In 2015, increased attention was paid to the impact of environmental taxes on reducing pollution, reducing emissions, climate change, which actualized their impact on technological innovation. The most modern research is already related to the complexity of applying environmental tax instruments in ensuring a green economy, reducing environmental degradation and carbon footprint, and developing and implementing environmental innovations.

Analysis of the empirical relationships that arise between the functioning of environmental taxes and the development of the oil and gas industry showed the existence of an inverse correlation in trends in environmental taxation and the pace of the oil and gas industry (Table 1), i.e., growth of tax revenues volumes of oil and gas production and consumption. 
A., Huseynov, E., Huseynov, Y., Samusevych. Innovative Development of Oil \& Gas Industry: Role of Environmental Taxation

Table 1. Correlation matrix of environmental tax revenues and oil \& gas production and

\begin{tabular}{|c|c|c|c|c|c|}
\hline Variables & $\begin{array}{c}\text { Environmental } \\
\text { tax revenues }\end{array}$ & $\begin{array}{c}\text { Oil } \\
\text { production }\end{array}$ & $\begin{array}{l}\text { Natural gas } \\
\text { production }\end{array}$ & $\begin{array}{c}\text { Oil } \\
\text { consumption }\end{array}$ & $\begin{array}{l}\text { Natural gas } \\
\text { consumption }\end{array}$ \\
\hline Environmental tax revenues & 1.000 & & & & \\
\hline Oil production & -0.145 & 1.000 & & & \\
\hline Natural gas production & -0.152 & 0.980 & 1.000 & & \\
\hline Oil consumption & -0.509 & 0.546 & 0.645 & 1.000 & \\
\hline Natural gas consumption & -0.140 & 0.943 & 0.980 & 0.703 & 1.000 \\
\hline
\end{tabular}

Sources: developed by the authors.

At the same time, it is important to identify causal links between the application of environmental taxes and the parameters of the oil and gas industry. Thus, the regression analysis results presented in Table 2 showed a statistically significant impact of environmental taxes on the production and consumption of oil and gas.

Table 2. Results of the regression analysis on testing the hypothesis about the influence of environmental taxation on central government revenues oil \& gas production and consumption

\begin{tabular}{|c|c|c|c|c|c|c|}
\hline \multicolumn{3}{|c|}{ Indicator } & \multicolumn{4}{|c|}{ Dependent variable } \\
\hline & & & Oil production & $\begin{array}{l}\text { Natural gas } \\
\text { production }\end{array}$ & Oil consumption & $\begin{array}{l}\text { Natural gas } \\
\text { consumption }\end{array}$ \\
\hline $\begin{array}{l}\text { Environmental } \\
\text { coefficient }\end{array}$ & $\operatorname{tax}$ & influence & $-47387.89^{* *}$ & $-2054.168^{* \star *}$ & $-9719.433^{* \star *}$ & $-1453.16^{* * *}$ \\
\hline Constant & & & 100046.7 & 4596.969 & 61014.48 & 3991.08 \\
\hline R-squared & & & 0.4751 & 0.6182 & 0.4209 & 0.6394 \\
\hline $\mathrm{F}$ & & & 7.80 & 17.22 & 11.89 & 20.62 \\
\hline Prob $>F$ & & & 0.0234 & 0.0032 & 0.0087 & 0.0019 \\
\hline
\end{tabular}

Notes: ${ }^{* * *} p<0.01,{ }^{* *} p<0.05,{ }^{*} p<0.1$

Sources: developed by the authors.

Note that this effect is reversed, i.e., increasing the share of environmental tax revenues in GDP is the cause of changes in both oil and gas production and consumption. It points to the fact that environmental taxation could cause a reduction in the extraction of natural resources within the country and their import from other countries. Thus, the generalized analysis confirms the previously identified theoretical patterns.

Conclusions. The study shows that global transformations due to the need to achieve the Sustainable Development Goals penetrate all sectors of the national economy. The analysis of logical-structural connections arising in the chain «innovative management - oil and gas industry - environmental taxes» showed the existence of the following patterns: 1) at the present stage the tasks of innovative management of industry are to ensure its competitiveness and balance of environmental and economic efficiency; 2) innovations in the development of the oil and gas industry are associated with the simultaneous search for directions for the introduction of energy and cost-effective technologies and maintaining competitiveness against the background of global transformations in the energy sector; 3 ) there is a shift in the emphasis of the impact of environmental taxation on the functioning of the oil and gas industry from limiting environmental pollution to a comprehensive restructuring; 4) the provision of environmentallyoriented innovations through the application of environmental taxes is achieved only in the process of their comprehensive interaction with direct state support for the green economy and the formation of a favorable institutional environment. Generalized empirical analysis proves that the increase in environmental taxation is the reason for reducing the production and consumption of oil and gas. It indicates the loss of 


\section{A., Huseynov, E., Huseynov, Y., Samusevych. Innovative Development of Oil \& Gas Industry: Role of Environmental}

Taxation

relevance of extensive development of the energy sector and the need for long-term strategies to replace energy in the national economy.

Given the significant role of the oil and gas industry, which persists both globally and its systemic impact on the national economy of individual countries, promising areas of further research are the analysis of regional structural differences in the transformation of the oil and gas industry, the transformation of the ratio of energy renewable energy, as well as the effectiveness of state support for innovative transformations in the oil and gas industry.

Funding: This paper was supported by the Ministry of Education and Science of Ukraine and performed the results of the projects «Structural-functional multiplex model of ecological tax system building in Ukraine in the context of national security» (registration number 0119U100759).

Author Contributions: conceptualization and methodology, A.H. and Y. S.; software, E. H.; validation, A. H. and E. H.; formal analysis and investigation, A. H. and Y. S.; resources, data curation A. H. and E. H., writing-original draft preparation, writing-review and editing, A. H. and Y. S.; visualization, E. H.; supervision, A. H., Y. S., and E. H.; project administration, A. H.

\section{References}

Acemoglu, D., Aghion, P., Bursztyn, L., \& Hemous, D. (2012). The environment and directed technical change. American economic review, 102(1), 131-66. [Google Scholar] [CrossRef]

Adetutu, M. O. (2014). Energy efficiency and capital-energy substitutability: Evidence from four OPEC countries. Applied Energy, 119, 363-370. [Google Scholar] [CrossRef]

Antonyuk, N., Plikus, I., \& Jammal, M. (2021). Sustainable business development vision under the covid-19 pandemic. Health Economics and Management Review, 2(1), 37-43. [Google Scholar] [CrossRef]

Bansal, P. (2005). Evolving sustainably: A longitudinal study of corporate sustainable development. Strategic management journal, 26(3), 197-218. [Google Scholar] [CrossRef]

Bhandari, M. P. (2019). Sustainable Development: Is This Paradigm The Remedy of All Challenges? Does Its Goals Capture The Essence of Real Development and Sustainability? With Reference to Discourses, Creativeness, Boundaries and Institutional Architecture. SocioEconomic Challenges, 3(4), 97-128. [Google Scholar] [CrossRef]

Biewendt, M. (2020). Sustainable Development: A Quantitative Analysis Regarding the Impact of Resource Rents on State Welfare from 2002 to 2017 . SocioEconomic Challenges, 4(4), 119-131. [Google Scholar] [CrossRef]

Bilan, Y., Streimikiene, D., Vasylieva, T., Lyulyov, O., Pimonenko, T., \& Pavlyk, A. (2019). Linking between Renewable Energy, CO2 Emissions, and Economic Growth: Challenges for Candidates and Potential Candidates for the EU Membership. Sustainability, 11, 1528. [Google Scholar] [CrossRef]

Bonamigo, A., \& Mendes, D. (2019). Value Co-creation and Leadership: An Analysis Based on the Business Ecosystem Concept. Business Ethics and Leadership, 3(4), 66-73. [Google Scholar] [CrossRef]

Berardi, P. C., \& de Brito, R. P. (2021). Supply chain collaboration for a circular economy-From transition to continuous improvement. Journal of Cleaner Production, 129511. [Google Scholar] [CrossRef]]

Christmann, P. (2020). Effects of «best practices» of environmental management on cost advantage: The role of complementary assets. Academy of Management Journal, 43(4), 663-680. [Google Scholar] [CrossRef]

Eddassi, H. (2020). Fiscal Regime and Tax Policy in Resource-Rich Countries In The Process Of Globalization: Literature Review. SocioEconomic Challenges, 4(2), 67-77. [Google Scholar] [CrossRef]

El Amri, A., Oulfarsi, S., Boutti, R., Sahib Eddine, A., \& Hmioui, A. (2021). Carbon Financial Markets Underlying Climate Change Mitigation, Pricing and Challenges: Technical Analysis. Financial Markets, Institutions and Risks, 5(1), 5-17. [Google Scholar] [CrossRef]

Fischer, C., Parry, I. W., \& Pizer, W. A. (2003). Instrument choice for environmental protection when technological innovation is endogenous. Journal of environmental economics and management, 45(3), 523-545. [Google Scholar] [CrossRef]

Ford, J. A., Steen, J., \& Verreynne, M. L. (2014). How environmental regulations affect innovation in the Australian oil and gas industry: Going beyond the Porter Hypothesis. Journal of Cleaner Production, 84(1), 204-213. [Google Scholar] [CrossRef]

Freire-González, J., \& Puig-Ventosa, I. (2019). Reformulating taxes for an energy transition. Energy Economics, 78, 312-323. [Google Scholar] [CrossRef]

Gil, E., Morales, Y. \&, Ochoa, T. (2021). Addressing the Effects of Climate Change on Modeling Future Hydroelectric Energy Production in Chile. Energies, 14(1), 241. [Google Scholar] [CrossRef]

He, S. (2019). The Impact of Trade on Environmental Quality: A Business Ethics Perspective and Evidence from China. Business Ethics and Leadership, 3(4), 43-48. [Google Scholar] [CrossRef] 
Ibragimov, Z., Vasylieva, T., \& Lyulyov, O. (2019). The National Economy Competitiveness: Effect of Macroeconomic Stability, Renewable Energy on Economic Growth. Economic and Social Development (ESD 2019): Proceedings of the 37th International Scientific Conference on Economic and Social Development - Socio Economic Problems of Sustainable Development, 878-887. [Google Scholar]

Kasztelnik, K., \& Gaines, V. W. (2019). Correlational Study: Internal Auditing and Management Control Environment Innovation within Public Sector in the United States. Financial Markets, Institutions and Risks, 3(4), 5-15. [Google Scholar] [CrossRef]

Kemp, R., \& Pontoglio, S. (2011) The innovation effects of environmental policy instruments - A typical case of the blind men and the elephant? Ecological Economics, 72, 28-36. [Google Scholar] [CrossRef]

Khan, M. A., \& Kishwar, A. (2020). Natural Resource Rent and Financial Development Nexuses in Bangladesh: The Role of Institutional Quality. Financial Markets, Institutions and Risks, 4(2), 108-114. [Google Scholar] [CrossRef]

Lyulyov, O., Pimonenko, T., Kwilinski, A., Dzwigol, H., Dzwigol-Barosz, M., Pavlyk, V., \& Barosz, P. (2021). The Impact of the Government Policy on the Energy Efficient Gap: The Evidence from Ukraine. Energies, 14(2), 373. [Google Scholar] [CrossRef]

Mishenina, H., Kirichenko, D., \& Puzemsky, V. (2021). COVID-19 impact on the company's development: a case of UNIT.City. Health Economics and Management Review, 2(2), 58-70. [Google Scholar] [CrossRef]

Pavlyk, V. (2020). Assessment of green investment impact on the energy efficiency gap of the national economy. Financial Markets, Institutions and Risks, 4(1), 117-123. [Google Scholar] [CrossRef]

Taliento, M., Netti, A. (2020). Corporate Social/Environmental Responsibility and Value Creation: Reflections on a Modern Business Management Paradigm. Business Ethics and Leadership, 4(4), 123-131. [Google Scholar] [CrossRef]

Teece, D. J., Pisano, G., \& Shuen, A. (1997). Dynamic capabilities and strategic management. Strategic Management Journal, 18(7), 509-533. [Google Scholar] [CrossRef]

Us, Ya., Pimonenko, T., Tambovceva, T., \& Segers, J. P. (2020). Green transformations in the healthcare system: the covid-19 impact. Health Economics and Management Review, 1(1), 48-59. [Google Scholar] [CrossRef]

Аріф Гусейнов, доктор наук, Азербайджанський державний університет нафти й промисловості, Азербайджан

Еміль Гусейнов, Науково-дослідний і проектний інститут нафти і газу, Азербайджан

Ярина Самусевич, к.е.н., Сумський державний університет, Україна

Інноваційний розвиток нафтогазової промисловості: роль екологічного оподаткування

Стаття присвячена дослідженню взаємозв'язку екологічних податків 3 інноваційним розвитком нафртогазової промисловості. Проведений бібліометричний аналіз напрямків наукових досліджень ланцюга «інноваційний менеджмент наффогазова промисловість - екологічні податки» засвідчив центральне місце проблематики сталого розвитку в забезпеченні інноваційних трансформацій промисловості. Визначено, що метою застосування екологічних податків $є$ не лише скорочення забруднення навколишнього природного середовища, а й забезпечення структурних трансформацій економіки на шляху до забезпечення ії сталого розвитку. Доведено, що інновації в нафтогазовій промисловості пов'язані не лише з імплементацією більш ефеккивних технологій, а й з пошуком перспектив ії трансформації відповідно до цілей зеленої економіки. Визначено, що застосування екологічних податків для стимулювання прогресу сталого розвитку потребує комплексності їх поєднання з іншими інструментами державної підтримки екологічних інновацій. Проведено емпіричний аналіз зв'язку екологічного оподаткування з показниками виробництва та споживання нафти й газу на основі статистичних даних для країн ОЕСР за період 2010-2019 років. За допомогою кореляційного аналізу визначено обернений зв'язок між динамікою індикаторів інтенсивності екологічного оподаткування та параметрів функціонування нафтогазової промисловості. Побудовані за методом стандартної похибки Ньюї-Веста регресійні залежності зміни обсягів виробництва та споживання нафтти й газу під впливом зміни надходжень від екологічного оподаткування підтвердили наявність оберненого зв'язку. Визначено, що при зростанні обсягу податкових надходжень від екологічних податків відбуваються суттєві скорочення як в обсягах виробництва, так і споживання нафтти й газу. Відповідно, підтверджено, що екологічні податки $є$ однією з причин інноваційних транссрормацій нафтогазової промисловості, пов'язаних зі зменшенням масштабів ї традиційного функціонування та переходом до більш прогресивних технологій виробництва енергоресурсів. Отримані результати є підґрунтям для коригування державних стратегій регулювання функціонування нафртогазової промисловості та забезпечення ії інноваційного розвитку.

Ключові слова: екологічне оподаткування, насртогазова промисловість, інновації, сталий розвиток, енергоефективність, стале зростання, промислові інновації. 